\title{
Lophomonas blattarum Associated Broncho- Pulmonary Infection After Immunotherapy: A Case Report and A Smart-phone Based Video of Trophozoite
}

\author{
Immünoterapi Sonrasinda Lophomonas blattarum ile İlişkili \\ Bronkopulmoner Enfeksiyon: Bir Olgu Sunumu ve Trofozoitin Akıllı \\ Telefon Kamerasi ile Çekilmiş Videosu
}

\author{
(1) Orçun Zorbozan ${ }^{1}$, (1) Ahmet Uysal ${ }^{2}$, (1) Feza Bacakoğlu², (1) Nevin Turgay ${ }^{1}$, (1) Seray Töz \\ ${ }^{1}$ Ege Üniversitesi Tıp Fakültesi, Tıbbi Parazitoloji Anabilim Dalı, İzmir, Türkiye \\ ${ }^{2}$ Ege Üniversitesi Tıp Fakültesi, Göğüs Hastalıkları Anabilim Dalı, İzmir, Türkiye
}

Cite this article as: Zorbozan O , Uysal A, Bacakoğlu F, Turgay N, Töz S. Lophomonas blattarum Associated BronchoPulmonary Infection After Immunotherapy: A Case Report and A Smart-phone Based Video of Trophozoite. Turkiye Parazitol Derg 2019;43(1):44-6.

\begin{abstract}
The frequency of bronchopulmonary protozoan infections has raised due to increased number of immunosuppressed patients in recent years. One of them is Lophomonas blattarum which is a multi-flagellated protozoan parasite of termites and several cockroach species. The drug regimens commonly used in bronchopulmonary infections are not effective against L. blattarum. Therefore, rapid and accurate diagnosis of L. blattarum infection is of great importance in the treatment success. The laboratory diagnosis of $L$. blattarum infection is made on the basis of observation of the characteristic trophozoite in various samples. It is of a great importance to distinguish the protozoon from ciliated respiratory epithelium to avoid wrong positivity. The presented case developed an acute respiratory distress syndrome a short while after taking nivolumab immunotherapy. The morphological features of L. blattarum were demonstrated by examining the bronchoalveolar lavage fluid of the patient under light microscopy. Additionally, URL (https://youtu.be/EQIAsFl6AJY) of a smart-phone based video of trophozoite of this patient was added into this report.
\end{abstract}

Keywords: Flagellated protozoon, immunotherapy, smart-phone video

Öz

Bronkopulmoner protozoon enfeksiyonlarının sıklığı son yıllarda immün yetmezlikli hastaların sayısındaki artışa bağlı olarak artmıştır. Bunlardan biri de termitlerin ve çeşitli hamam böceği türlerinin çoklu kamçll protozoon paraziti olan Lophomonas blattarum'dur. Bronkopulmoner enfeksiyonlarda yaygın olarak kullanılan ilaç rejimleri L. blattarum'a karşı etkili değildir. Bu nedenle tedavi başarısında L. blattarum enfeksiyonunun hızlı ve doğru tanısı büyük öneme sahiptir. Lophomonas blattarum enfeksiyonunun laboratuvar tanısı karakteristik trofozoitin çeşitli örneklerde gözlenmesine dayanır. Yalancı pozitiflikten kaçınmak için protozoonun silli solunum epitelinden ayırt edilmesi büyük öneme sahiptir. Sunulan olgu nivolumab immünoterapisinden hemen sonra gelişen bir akut respiratuvar distress sendromu olgusudur. Hastanın bronkoalveolar lavaj sıvısı 1şık mikroskobunda incelenerek L. blattarum'un morfolojik özellikleri ortaya konmuştur. Ek olarak, hastanın trofozoitinin akıllı telefon kamerası ile elde edilmiş video URL'si (https://youtu.be/EQIAsFl6AJY) olgu sunumuna eklenmiştir.

Anahtar Kelimeler: Kamçılı protozoon, immünoterapi, akıllı telefon videosu

Received/Geliș Tarihi: 21.05.2018 Accepted/Kabul Tarihi: 03.12.2018

Address for Correspondence/Yazar Adresi: Orçun Zorbozan MD, Ege Üniversitesi Tip Fakültesi, Tibbi Parazitoloji Anabilim Dalı, İzmir, Türkiye Phone/Tel: +90 2323904916 E-mail/E-Posta: orcun-zorbozan@hotmail.com ORCID ID: orcid.org/0000-0002-9645-7085 


\section{INTRODUCTION}

Lophomonas species are members of the super group Excavata, first rank Parabasalia, and second rank Cristamonadida in protozoa (1). Lophomonas blattarum is a commensal multi-flagellated protozoan parasite of termites and several cockroach species including Blatta orientalis, Periplaneta americana and Blatella germanica (2). It also has been described in certain bird's faeces named Chlamydotis undulata (3). It is shed by the faeces of the host to the environment and encysts in external environmental conditions. The cyst form may be inhaled and parasitize in human respiratory tract and can cause sinusitis or broncho-pulmonary infection (4). Lophomonas blattarum is a rare but serious infectious agent of broncho-pulmonary region (4-6). It is difficult to distinguish Lophomonas associated broncho-pulmonary infection from common infections with similar symptoms. Antibacterial, antifungal or antiviral drugs that are used in common bronchopulmonary infections are not effective against L. blattarum (5). Rapid and accurate diagnosis of L. blattarum infection is of great importance in the treatment success.

The laboratory diagnosis of L. blattarum infection is made on the basis of observation of the characteristic flagellated protozoa in various samples as sputum, broncho-alveolar lavage or tracheal aspirate. Characteristic protozoon is ovoid, round or piriform in shape, $20-60 \mu \mathrm{m}$ in length and $12-20 \mu \mathrm{m}$ in width. It has a granulated cytoplasm with phagocyted food particles. On the apex, it has a tuft of several irregular flagella on a round basis. The nucleus is seen as a round body near the insertion of the flagella (3). It is of a great importance to distinguish the protozoon from ciliated respiratory epithelium to avoid wrong positivity (7-9).

\section{CASE REPORT}

A 68 years-old male patient was admitted to the Ege University Hospital, Department of Emergency Medicine with dyspnea symptom which was occurred in a short while after taking nivolumab immunotherapy for metastatic lung carcinoma and the patient was hospitalized in Respiratory Intensive Care Unit of Chest Diseases department with acute respiratory distress syndrome (ARDS) on March 3, 2016. Moxifloxacin (1x1), meropenem (3x1) and oseltamivir (2x1) treatment was started and respiration was supported with non-invasive mechanical

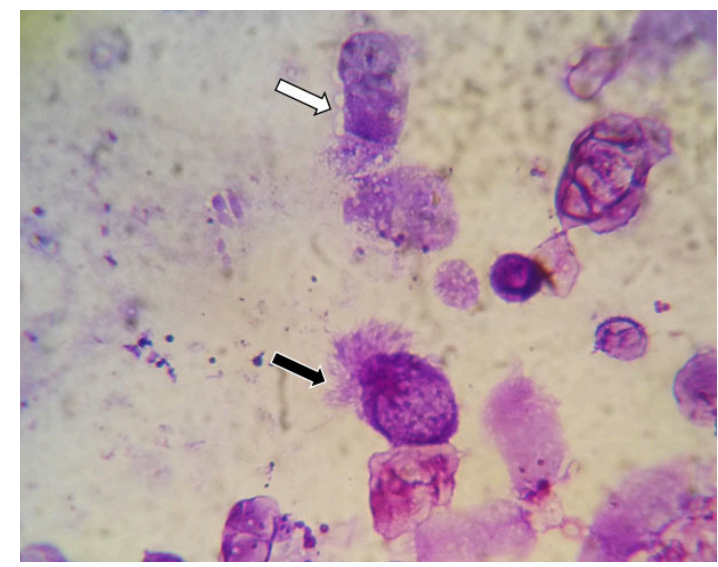

Figure 1. L. blattarum trophozoite (black arrow) and bronchial epithelium (white arrow) on Giemsa staining of bronchoalveolar lavage fluid smear (magnification x1000) ventilation. Arterial blood gas was monitored and albumin replacement therapy was started. Respiration was supported with continuous positive airway pressure (CPAP) at $12 \mathrm{cmH}_{2} \mathrm{O}$ pressure and $\mathrm{FiO} 2$ 80\% on March 07, 2016. Cefoperazon sulbactam treatment was started due to increased pulmonary secretion on March 16, 2016. Colistin and tigecycline treatment were started on March 18, 2016 because of the lack of response to the cefoperazon sulbactam treatment. Postero-anterior chest $\mathrm{X}$-ray showed left lower zone and more intensive right lower and middle zone consolidation, the right-mid-zone suprahilar regions contained air bronchograms and the diaphragm contours on the left were not observed. Bronchoscopy and broncho-alveolar lavage were performed on March 18, 2016. Motile and flagellated trophozoites were seen in direct microscopic examination of broncho-alveolar lavage fluid after centrifugation at $2000 \mathrm{rpm}$ for 15 minutes. The motility and morphologic features of trophozoites were recorded with mobile phone camera recorder (Video 1; URL: https://youtu.be/EQIAsFl6AJY). On the Giemsa staining of broncho-alveolar lavage fluid smear (Figure 1); the trophozoite was piriform in shape and had a tuft of several flagella on the apex, no terminal bar structure was present. The cytoplasm was in a granular appearance. The insertion of flagella was semicircle in shape and the length of each flagella were different. The body was unstriated. The trophozoites were evaluated as L. blattarum. No accompanying microorganisms were detected in broncho-alveolar lavage fluid. Metronidazole $500 \mathrm{mg}$ tab twice a day treatment was started on the day of L. blattarum diagnosis (March 18, 2016). The patient died due to cardio-pulmonary dysfunction on March 21, 2016.

\section{DISCUSSION}

The frequency of broncho-pulmonary protozoan infections has raised due to increased number of immunosuppressed patients in recent years. Immunosuppression in the respiratory tract can be due to human immunodeficiency virus infection, long-term use of immunosuppressive therapies, cancer, systemic illness, geriatric conditions, or chronic respiratory pathology $(3,10)$. The presented case is an ARDS which was occurred in a short while after taking nivolumab immunotherapy.

The identification of $L$. blattarum has been based on the identification of microscopic morphological features using fresh and stained samples of sputum, broncho-alveolar lavage fluid, bronchial brushing and tracheal aspirate. It is difficult to differentiate multi-flagellated protozoa from ciliated bronchial epithelial cells, and this situation causes a significant risk of misidentification under light microscopy. It is possible for "detached ciliary tufts" (also described as "Ciliocytophthoria" phenomena) to be confused with protozoa in sputum samples. Cytoplasmic remnants with cilia are a frequent finding in the bronchial secretions from patients with obstructive pulmonary disease and asthma (8). Parasitic infection caused by the multiflagellated protozoon L. blattarum has been described (11), and its presence in respiratory secretions, in both fresh and stained smears, has been observed (12). Therefore, we aimed to draw attention to the importance of accurate microscopic diagnosis of L. blattarum in this case report.

In the presented case, morphological features of L. blattarum was demonstrated under light microscopy. Differential diagnosis from ciliated bronchial epithelial cells was done with key morphological 
features such as ovoid shape of the cell, tuft of numerous and irregular flagella originated from a round basis, granular cytoplasm and absence of terminal bar. Additionally, pattern of the motility of L. blattarum was demonstrated with a smartphone based video of light microscopic examination. This is the first report which demonstrated the morphology and motility of L. blattarum with a video of light microscopic examination.

\section{CONCLUSION}

Lophomonas associated broncho-pulmonary infection is hard to distinguish from common infections with such clinical features. The drug regimens commonly used in broncho-pulmonary infections are not effective against L. blattarum. Therefore, rapid and accurate diagnosis of L. blattarum infection is of great importance in the treatment success. Microscopy professionals should consider L. blattarum infection while evaluating respiratory specimens of immunosuppressed patients. Direct microscopy of fresh sample should be evaluated to detect the motile trophozoite forms of this flagellated protozoan parasite.

\section{* Ethics}

Informed Consent: Non-applicable

Peer-review: Internally peer-reviewed

\section{* Authorship Contributions}

Concept: N.T., F.B., O.Z., S.T., Design: N.T., F.B., O.Z., S.T., Data Collection or Processing: O.Z., A.U., Analysis or Interpretation: O.Z., A.U., Literature Search: O.Z., A.U., Writing: O.Z., A.U.

Conflict of Interest: No conflict of interest was declared by the authors.

Financial Disclosure: The authors declared that this study received no financial support.

\section{REFERENCES}

1. Adl SM, Simpson AGB, Farmer MA, Andersen RA, Anderson OE, Barta JR, et al. The new higher level classification of eukaryotes with emphasis on the taxonomy of protists. J Eukaryot Microbiol 2005;52:399451.

2. Alam-Eldin YH, Abdulaziz AM. Identification criteria of the rare multiflagellate Lophomonas blattarum: comparison of different staining techniques. Parasitol Res 2015;114:3309-14.

3. Martínez-Giron R, van Woerden HC. Lophomonas blattarum and bronchopulmonary disease. J Med Microbiol 2013;62:1641-8.

4. Guozhong Y. Bronchopulmonary infection with lophomonas blattarum: two cases report and literature review. Journal of Medical Colleges of PLA 2008;23:176-82.

5. Xue J, Li YL, Yu XM, Li DK, Liu MF, Qiu JF, et al. Bronchopulmonary Infection of Lophomonas blattarum: A Case and Literature Review. Korean J Parasitol 2014;52:521-5.

6. Zhang X, Xu L, Wang LL, Liu S, Li J, Wang X. Bronchopulmonary Infection with Lophomonas blattarum: a Case Report and Literature Review. J Int Med Res 2011;39:944-9.

7. Martínez-Girón R, van Woerden HC. The burden of Lophomonas blattarum under the light microscope. J Thorac Dis 2014;6:E191-2.

8. Martínez-Girón R, van Woerden HC, Doganci L. Lophomonas misidentification in bronchoalveolar lavages. Intern Med 2011;50:2721; author reply 2723.

9. Martínez-Girón R, van Woerden HC. Bronchopulmonary lophomoniasis: emerging disease or unsubstantiated legend? Parasit Vectors 2014;7:284.

10. Kilimcioğlu AA, Havlucu Y, Girginkardeşler N, Çelik P, Yereli K, Özbilgin A. Putative Bronchopulmonary Flagellated Protozoa in Immunosuppressed Patients. Biomed Res Int 2014;2014:912346.

11. Vijayan VK, Kilani T. Emerging and established parasitic lung infestations. Infect Dis Clin North Am 2010;24:579-602.

12. Martínez-Girón R: Protozoal infections. In Parasitic diseases of the lungs. Edited by Barrios R, Haque AK. New York: Springer-Verlag; 2013:47-68. 